\title{
PASAR TRADISIONAL DENGAN PENATAAN MODERN DI KOTA MAKASSAR
}

\author{
Wasilah 1, St. Aisyah Rahman 2, Muhammad Misbahuddin ${ }^{3}$ \\ Jurusan Arsitektur Fakultas Sains \& Teknologi UIN-Alauddin Makassar \\ e-mail: *1 aisysipala@gmail.com, ${ }^{2}$ wasilah@uin-alauddin.ac.id, , ${ }^{3}$ mmisbah@gmail.com
}

\begin{abstract}
Abstrak_ Pasar Tradisional selama ini kebanyak terkesan kumuh, kotor, dan kurang tertata yang merupakan stigma buruk yang dimilikinya. Pasar Tradisional Lelong yang berada di Kecamatan Mariso (Jl. Rajawali) yang sudah lama dan masih aktif sampai sekarang selalu dipadati oleh pengunjung sehingga mengakibatkan kemacetan di kawasan sekitar pasar terlebih lagi pada waktu-waktu akhir pekan. Ruang parkir kendaraan dan orang-orang tumpah menjadi satu memenuhi jalanan di kawasan sekitar tapak, mereka harus berbagi berebut space yang sudah sangat kecil yang tidak dapat menampung keseluruhan pedagang yang berada di pasar tersebut sehingga badan jalan juga digunakan sebagai tempat parkir maupun ajang transaksi. Tujuan perancangan ini adalah menyusun suatu acuan perancangan yang dapat menjadi panduan dalam merancang pasar tradisional dengan penataan modern yang efektif dan efisien yang siap ditransformasikan dalam program perancangan fisik bangunan. Hasil dari laporan ini meninjau hal-hal yang spesifik dari bangunan, berupa syarat-syarat perencanaan yang meliputi konsep pengolahan tapak, bentuk bangunan, struktur bangunan, material bangunan, penataan ruang dalam dengan menganalisa permasalahan dan potensi yang ada pada pasar berdasarkan prinsip arsitektur modern.
\end{abstract}

Kata kunci : Pasar Tradisional, Padat, Penataan Modern.

Abstract_During the time traditional markets is empressed dirty, filthy, disorganized and so on, which has a bad stigma. Traditional Market Lelong in Mariso (Jl. Rajawali) is still exist and active longer with always crowded by the visitors that caused traffic jam around the market especially on the weekend. Vehicle parking spaces and people spilled into the streets at around site, they should share the very small space that can not accommodate the all traders are in the market so that the road is also used as a parking lot or transaction event. The purpose of this design is to develop a reference design that can be a guide in designing traditional markets and modern structuring effectiving and efficienting that are ready to be transformed into the physical design of the building program. The results of this report reviews the specifics of the building, such as the terms of the planning involved in processing concept site, shape buildings, building structure, building materials, the arrangement of inside space with analyzing the problems and the potential that exists in the market based on the principles of modern architecture.

Keywords : Traditional Market, Crowded, Modern Design

\footnotetext{
${ }^{1}$ Dosen Jurusan Teknik Arsitektur UIN Alauddin Makassar

${ }^{2}$ Dosen Jurusan Teknik Arsitektur UIN Alauddin Makassar

${ }^{3}$ Alumni Jurusan Teknik Arsitektur UIN Alauddin Makassar Angkatan 2015
} 


\section{PENDAHULUAN}

Pasar Tradisional selama ini kebanyakan terkesan kumuh, kotor, semrawut, bau dan seterusnya yang merupakan stigma buruk yang dimilikinya. Melekatnya stigma buruk pada pasar tradisional, seringkali mangakibatkan sebagian dari para pengunjung mencari alternatif tempat belanja lain, diantaranya mengalihkan tempat berbelanja ke pedagang kaki lima dan pedagang keliling yang lebih relatif mudah dijangkau (tidak perlu masuk pasar). Bahkan kebanyakan para pengunjung yang tergolong di segmen berpendapatan menengah bawah ke atas cenderung beralih ke pasar modern, seperti pasar swalayan (supermarket dan minimarket) yang biasanya lebih mementingkan kebersihan dan kenyamanan sebagai dasar pertimbangan beralihnya tempat berbelanja. (https://www.facebook.com/sppitegal/posts/1404762759745530)

Dalam Nahdliyul Izza (2010:4), Muhammad Aziz Hakim dalam bukunya yang berjudul Menguasai Pasar Mengeruk Untung (2005) bahwa, "Pasar selama ini sudah menyatu dan memiliki tempat paling penting dalam kehidupan masyarakat sehari- hari, bagi masyarakat pasar bukan hanya tempat bertemunya antara penjual dan pembeli tetapi juga sebagai wadah untuk berinteraksi sosial". Para ahli ekonomi mendiskripsikan sebuah pasar sebagai kumpulan penjual dan pembeli yang melakukan transaksi atas suatu produk tertentu atau kelompok produk tertentu.

Di Indonesia, terdapat kurang lebih terdapat 13.450 pasar tradisional atau dalam hal ini pasar lokal yang aktif yang menampung sekitar 12,6 juta pedagang. Sementara di Kota Makassar sendiri, berdasarkan hasil observasi yang dilakukan oleh Active Society Institute (AcSI) sepanjang tahun 2008 jumlah pasar lokal sudah mencapai lebih 50 buah. 16 pasar diantaranya oleh pemerintah kota dikategorikan sebagai pasar tradisional resmi dan 34 pasar atau selebihnya adalah pasar tradisional darurat atau liar, sebuah penamaan yang mendiskreditkan pedagang-pedagang kecil yang tidak tertib (AcSI,2009) (https://www.academia.edu/8745988/Pencemaran_Air_di_Pasar_ Terong). Namun saat ini kondisi visual pasar yang kumuh, becek, dan kios yang tidak teratur serta kapasitas pasar-pasar yang ada di Makassar tidak mampu mewadahi semua pedagang yang mengakibatkan banyaknya penjual menjajakan dagangannya dibadan jalan sehingga memicu terjadinya kemacetan disekitar pasar-pasar tersebut. Sampah berserakan di gang-gang antar kios dan berceceran di tempat pembuangan sampah sementara (TPS) yang kapasitasnya tidak memadai. Hal-hal ini sangat berpengaruh dari segi keamanan dan kesehatan.

Berdasarkan permasalahan diatas, maka diperlukan adanya pasar tradisional dengan penataan modern di Kota Makassar sebagai pasar tradisional yang mampu mengakomodir kebersihan, keamanan, dan kenyataan dalam bertransaksi, sehingga dapat mewujudkan pasar tradisional yang sehat, aman, dan nyaman. Pasar tradisional dengan konsep modern ini juga diharapkan mampu menyediakan fasilitas-fasilitas perdagangan demi kelancaran aktifitas perdagangan di Kota Makassar, sehingga dalam perkembangan selanjutnya pasar tradisional dengan konsep modern ini dapat menjadi icon baru yang menjadi kebanggaan Kota Makassar.

Pasar tradisional dengan penataan modern ini bukan berarti sama dengan supermarket atau swalayan, melainkan masih tetap sama dengan pasar tradisional. Pasar Modern ini akan menghasilkan pasar tradisional yang terkesan bersih dan tidak berbau, tidak becek dan tidak kumuh seperti halnya di pasar tradisional yang sering kita jumpai saat ini. Pembeli dan penjual masih tetap dapat berjumpa dan melakukan tawar-menawar ataupun bersilaturrahmi, karena kita juga pasti tau ikatan penjual di pasar tradisional sangat erat dengan langganannya. 


\section{METODOLOGI}

Metode yang digunakan dalam pembahasan meliputi :

1. Tahap Pengumpulan Data

a. Studi Literatur, dengan mengambil studi literatur dari buku-buku yang berkaitan dengan penulisan untuk mendapatkan teori, spesifikasi, dan karakteristik serta aspek-aspek arsitektural yang dapat dijadikan landasan dalam proses perancangan.

b. Studi Preseden, dengan mengambil studi preseden melalui internet mengenai pasar tradisional dengan penataan modern yang terdapat di Indonesia maupun di luar negeri.

c. Studi Lapangan, dilakukan survey lapangan untuk mengetahui dan mengamati kondisi yang akan menunjang terhadap perancangan.

2. Tahap Analisis, yaitu melakukan analisis dari data yang telah dikumpulkan memalui survey lokasi dan diolah ke dalam konsepsi perancangan bangunan pasar.

3. Aplikasi Desain , berupa hasil dari analisis konsepsi.

\section{LOKASI PERANCANGAN}

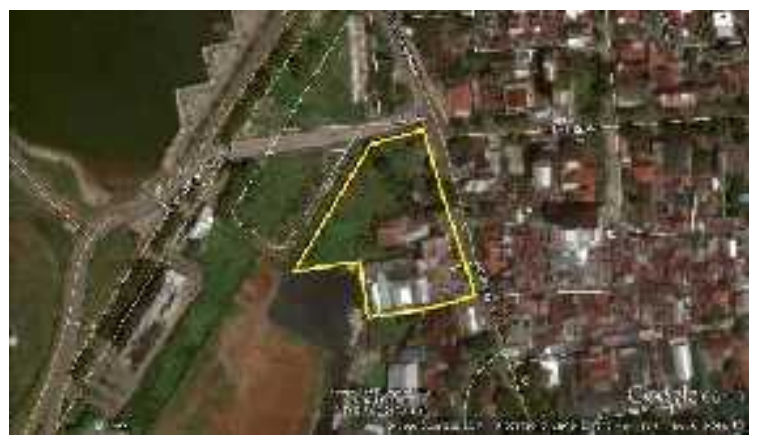

Gambar. Lokasi Perancangan, Jalan Rajawali

(Sumber : www.googleearth.com, 8 april 2015, 21:21 WITA)

Lokasi perancangan pasar tradisional dengan penataan modern di Makassar terletak di Pasar Lelong kecamatan Mariso dengan informasi lain:
1. Luas lahan
: $6657 \mathrm{~m} 2$ / 1,6657 Hektar
2. Lebar Jalan Primer
: 10 m (Jl. Rajawali Makassar)
3. Lebar Jalan Sekunder
: 8 m, (Jl. HM. Daeng Patompo)
4. Jumlah Pedagang kaki lima
$: 150$ Orang
5. Jumlah Pedagang Pasar Darurat : 63 Orang

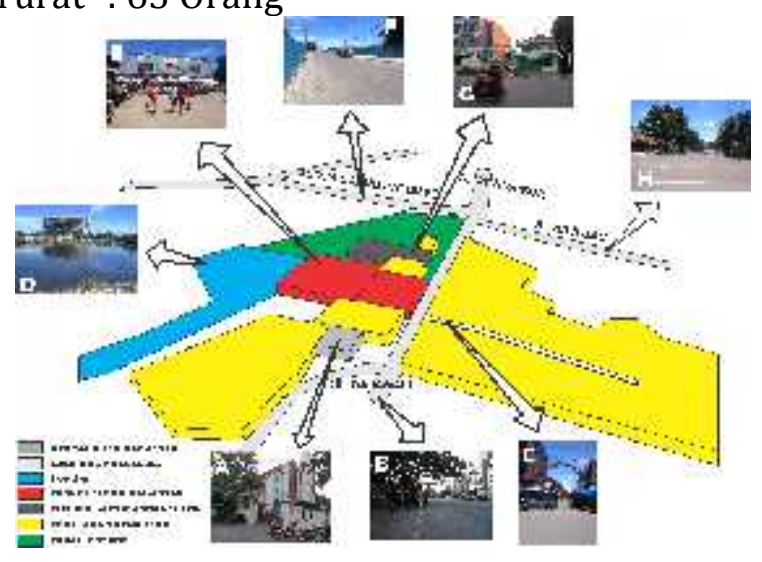

Gambar. Batas-batas Wilayah dan Kondisi Lingkungan Perancangan disekitar Tapak Sumber : Olah Data Lapangan, 9 April 2015, 08:49 WITA 
Kondisi lingkungan tapak memiliki beberapa potensi dan hambatan yang dapat mempengaruhi dalam proses perancangan. Adapun potensi yang dimiliki dari tapak ini yaitu :

1. Berada di daerah pemukiman sehingga dapat memenuhi kebutuhan pangan masyarakat sekitar.

2. Pencapaian mudah dan dapat terjangkau sarana transportasi.

3. Tersedia jaringan utilitas serta jaringan jalan kota.

4. Berada di daerah komersil seperti hotel dan pusat jajanan makanan khas Kota Makassar.

5. Masih adanya tanah kosong disekitar tapak yang bisa di manfaatkan untuk perencanaan Pasar Tradisional dengan Penataan Modern.

6. Lokasi tapak (Pasar Lelong) sudah dikenal di Kota Makassar.

7. Dekat dengan anjungan pantai losari.

Hambatan dari tapak ini yakni :

1. Adanya bangunan yang berada dilokasi perencanaan.

2. Kurangnya lahan parkir yang tersedia sehingga banyak pembeli yang memarkir kendaraan di bahu jalan

3. Site merupakan lokasi Pasar Lelong yang dalam kondisi fisiknya hanya diperuntukkan untuk menjadi pasar ikan yang luasannya tidak mencukupi seluruh pedagang, sehingga para pedagang sayur-sayuran dan pedagang rempah-rempah yang tidak tertampung dalam pasar tersebut menjajakan dagangannya dibahu jalan disekitar pasar lelong.

\section{PEMBAHASAN DAN HASIL}

\section{A. Desain Tapak}

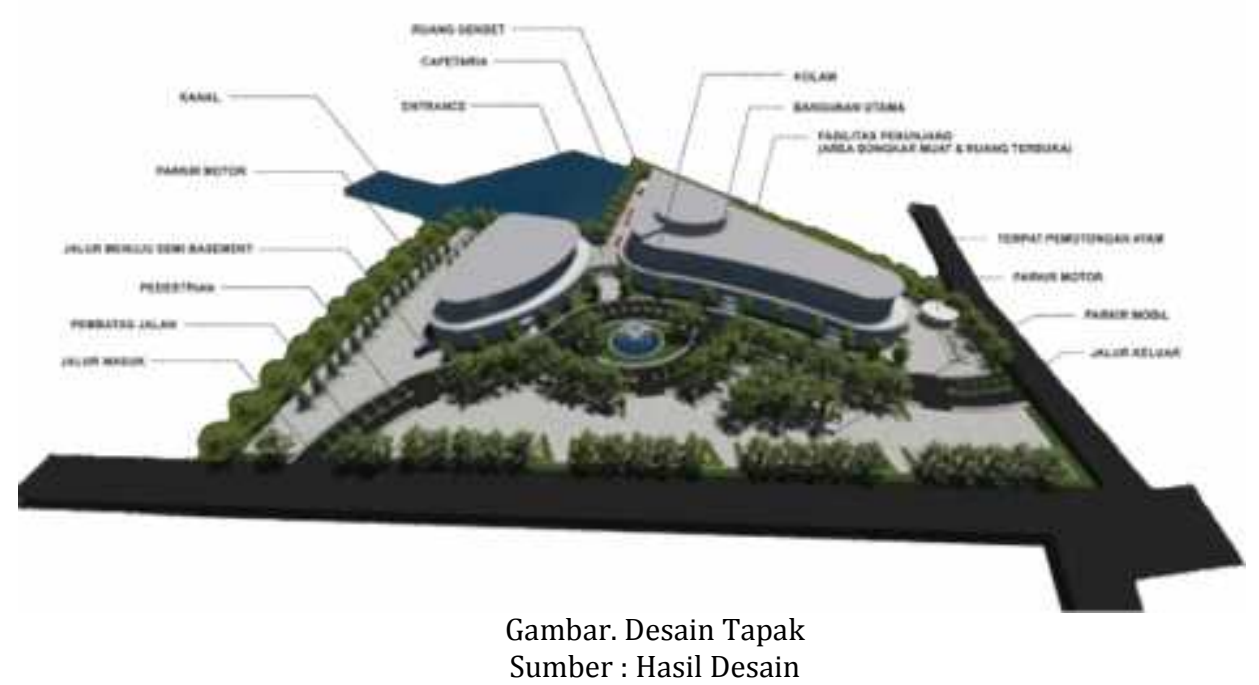

Konsep tapak terdiri dari perancangan desain berdasarkan konsep-konsep arsitektural yakni:

1. View tapak yang berpotesi ialah berada di Jl. Rajawali, untuk itu fasad harus diolah

2. Untuk mengatasi kebisingan, vegetasi dan membatasi dengan didnding beton 

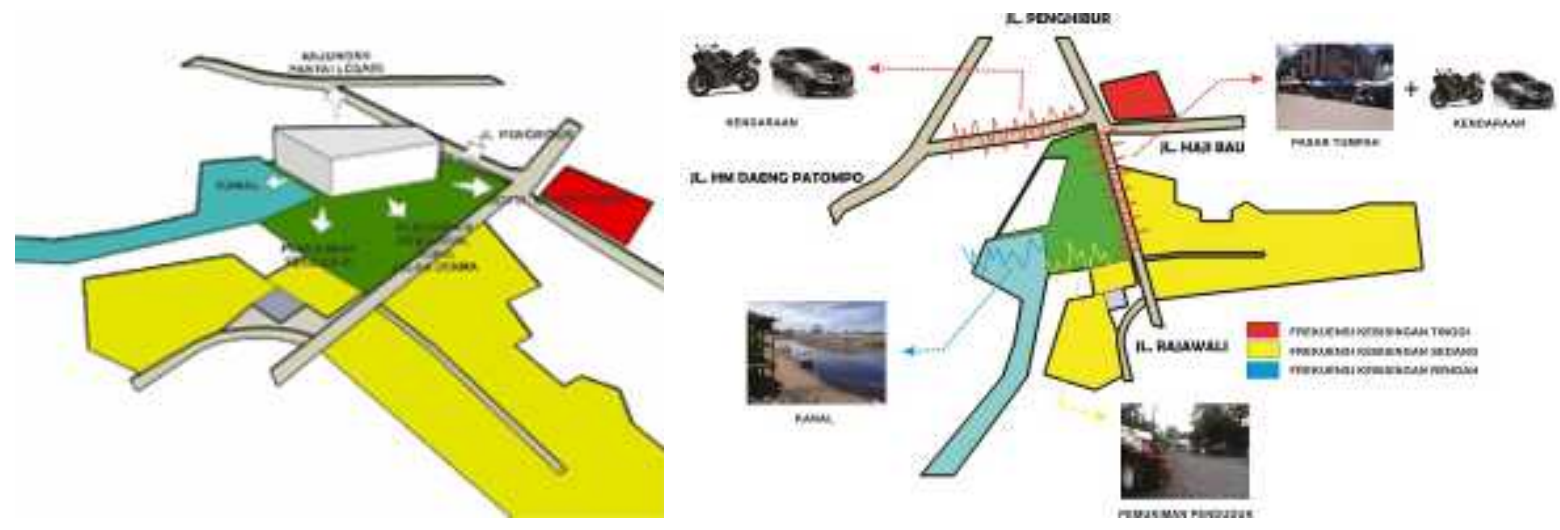

Gambar. Analisi View Tapak dan Kebisingan

(Sumber : Olah Desain, 1 Mei 2015)

3. Bangunan diarahkan menurut orientasi Timur-Barat dengan memaksimalkan bukaan pada bagian Selatan-Utara. Pemanfaatan sinar matahari sebagai pencahayaan matahari, serta didukung dengan penggunaan material kaca, Memberi material pelindung untuk menghidari panas dan silau.

4. Rencana penzoningan pada pasar tradisional dengan penataan modern terbagi 3, yaitu zona publik, zona semi-publik dan zona privat. Zona publik (warna kuning) terdiri dari lahan parkir, ruang terbuka hijau, ruang bersantai tempat berjualan dan food court diletakkan pada zona yang mudah dicapai serta dekat dari jalan utama. Zona semi-publik (warna hijau) merupakan daerah ruang-ruang administrasi maupun ruang mengunggu diletakkan pada zona yang mempunyai tingkat kebisingan sedang. Zona privat (warna merah) yang merupakan area perkantoran diletakkan pada zona yang mempunyai tingkat kebisingan rendah. Zona servis (warna ungu) diletakkan pada zona yang mudah diakses oleh kendaraan sehingga mudah dalam proses maintenance.

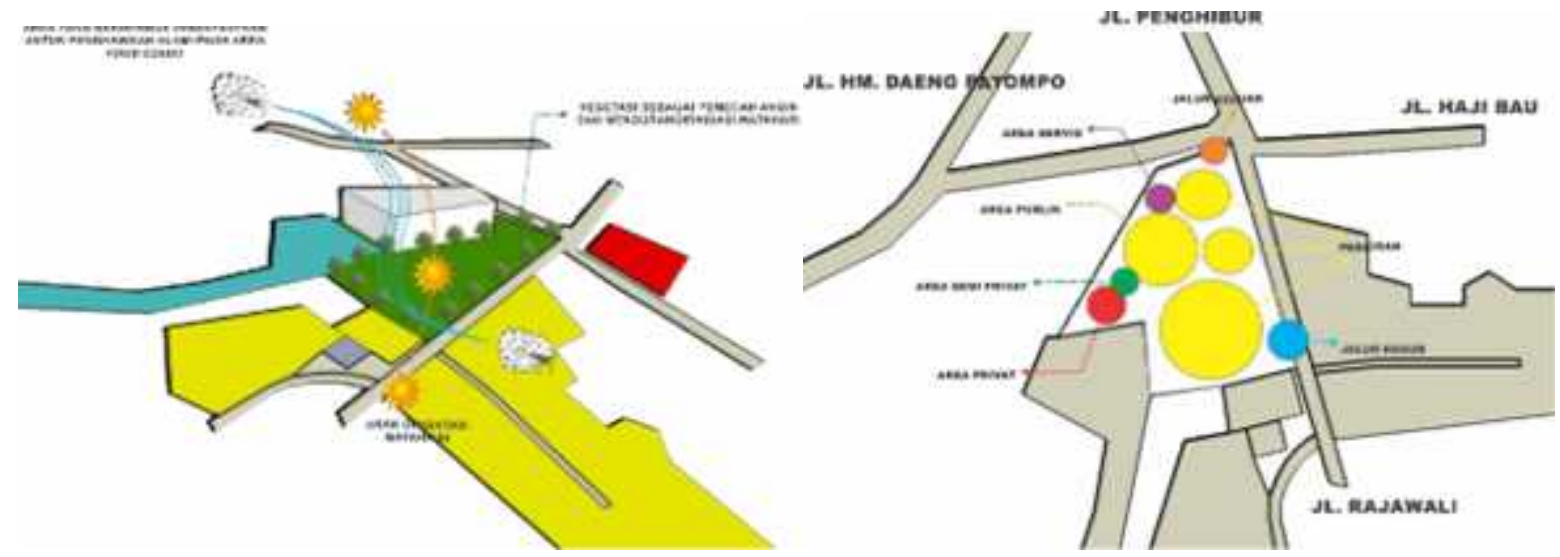

Gambar. Analisi Orientasi Matahari dan Perzoningan (Sumber : Olah Desain, 1 Mei 2015)

5. Sirkulasi menuju tapak pasar dengan kendaraan dan berjalan kaki dapat ditempuh melalui pintu masuk utama (entrance) yaitu dari Jalan Rajawali dan pintu keluar (exit) melalui Jalan HM. Daeng Patompo.

6. Cara mengantisipasi pasar tumpah yang suatu saat terjadi ketika menjelang perayaan hari-hari raya seperti tahun baru, hari raya Idul Fitri dan Hari Raya Idul adha dan sebagainya, disediakan tempat dibelakang bangunan utama agar tidak mengganggu pandangan langsung ke bangunan utama serta tidak mengganggu sirkulasi utama menuju bangunan pasar. 
Aisyah, Wasilah, Misbahuddin

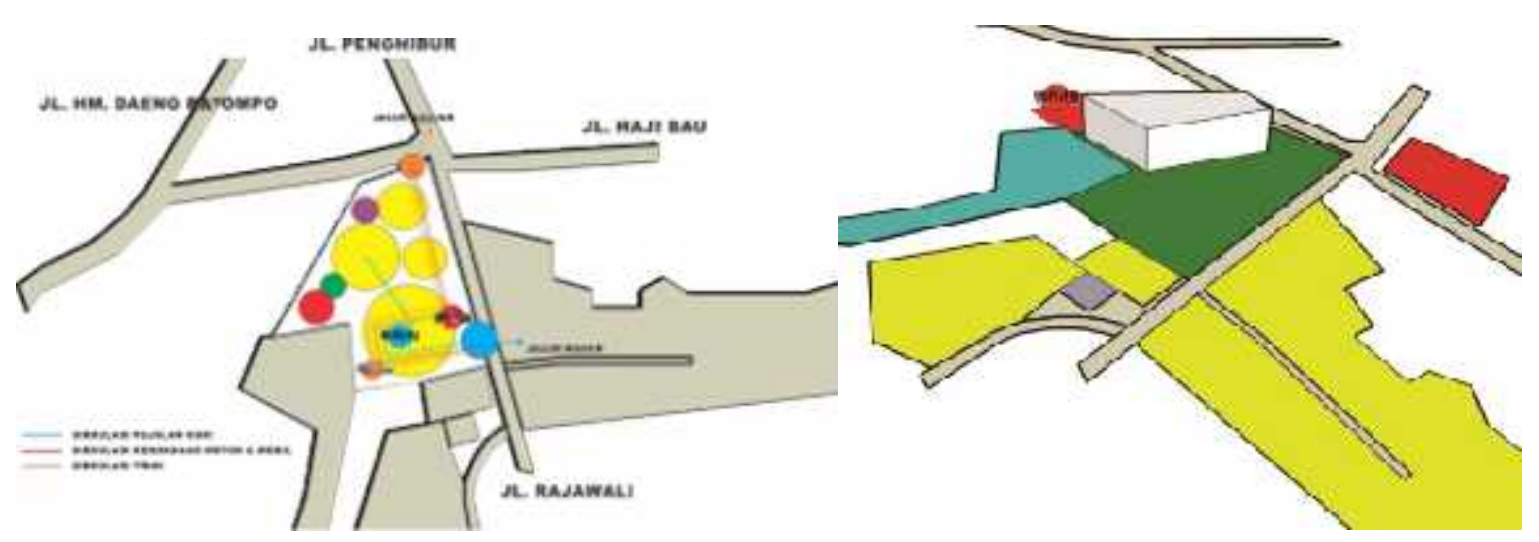

Gambar. Analisi Sirkulasi dan Pendekatan dalam Mengantisipasi Pasar Tumpah (Sumber : Olah Desain, 1 Mei 2015)

\section{B. Bentuk}

1. Bentuk Bangunan mengikuti kondisi tapak serta hasil dari pengolahan tapak dan pengolahan zoning..

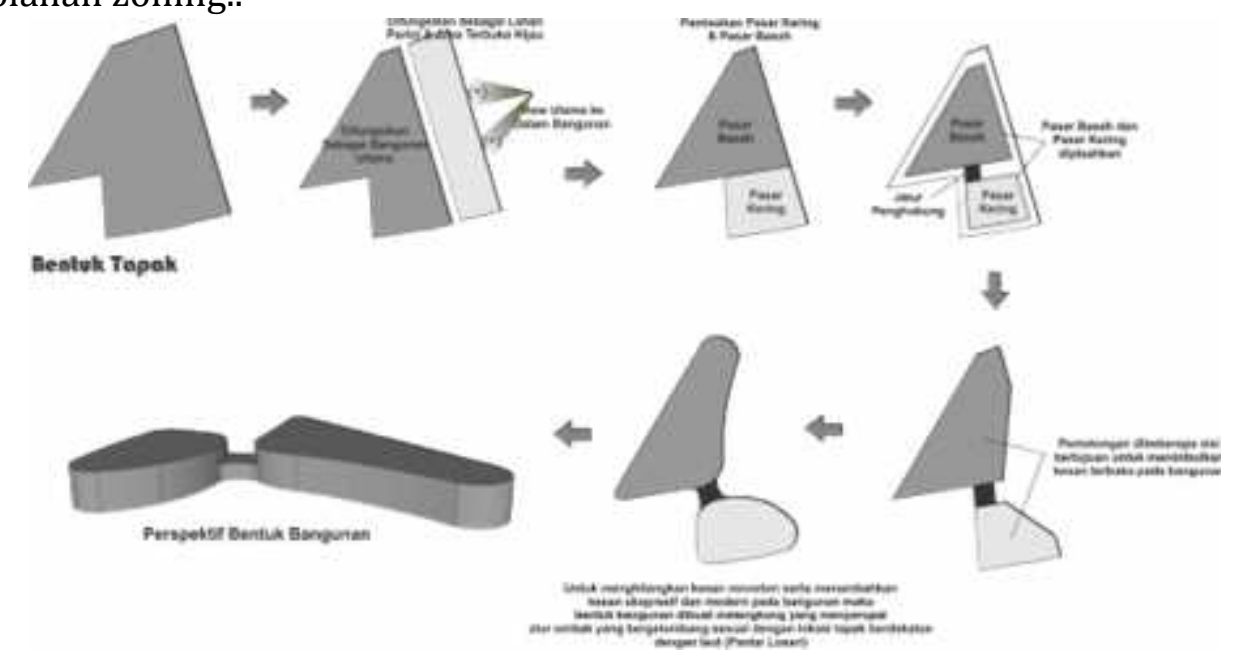

Gambar. Konsep Bentuk Sumber : Olah Desain, 2015

2. Bentuk Fasad, diambil dari filosofi ikan dan air untuk mempertahankan ciri khas dari tapak yang terpilih (Pasar Lelong). Pemilihan material Fasade juga memperhatikan bahan yang bisa disesuaikan dengan bentuk fasade serta dapat digunakan sebagai pemanfaatan penghawaan alami pada bangunan.
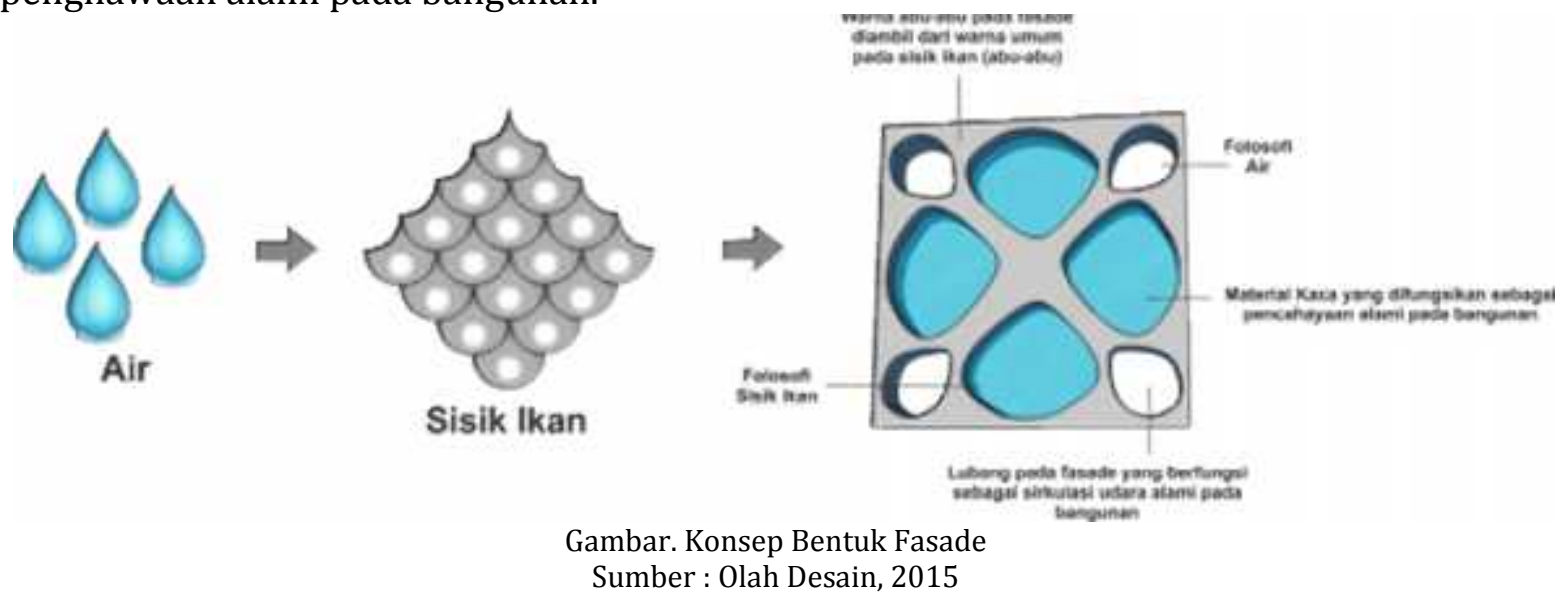

Gambar. Konsep Bentuk Fasade Sumber : Olah Desain, 2015 
3. Bentuk atap bangunan tetap mengikuti bentuk dasar bangunan tetapi dimodifikasi dengan melakukan perbedaan tingkat elevasi. Adapun tingkat elevasi atap bangunan pasar diambil dari filosofi segmentasi pasar yang mengincar tiga strata sosial yaitu segmentasi atas, menengah dan bawah.

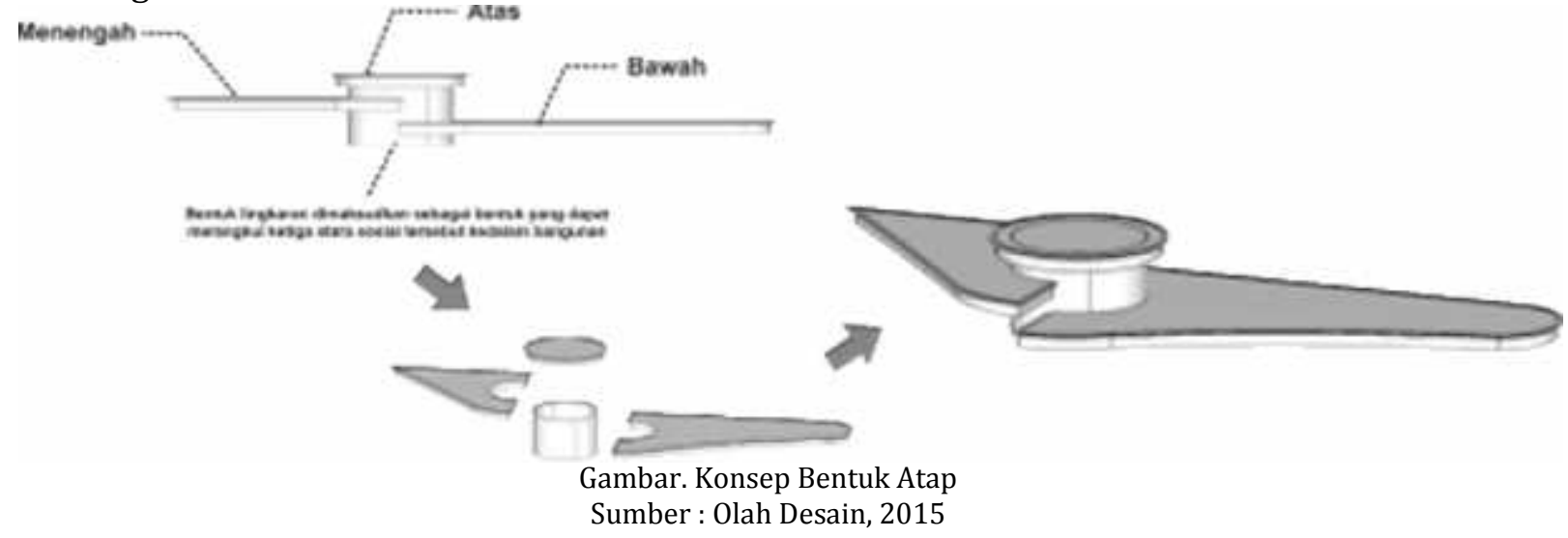

\section{Struktur, Material dan Double Façade}

1. Sub struktur bangunan memakai konstruksi pondasi tiang pancang. Pondasi tiang pancang dibuat menjadi satu kesatuan yang monolit dengan menyatukan pangkal tiang pancang yang terdapat di bawah konstruksi dengan tumpuan pondasi.

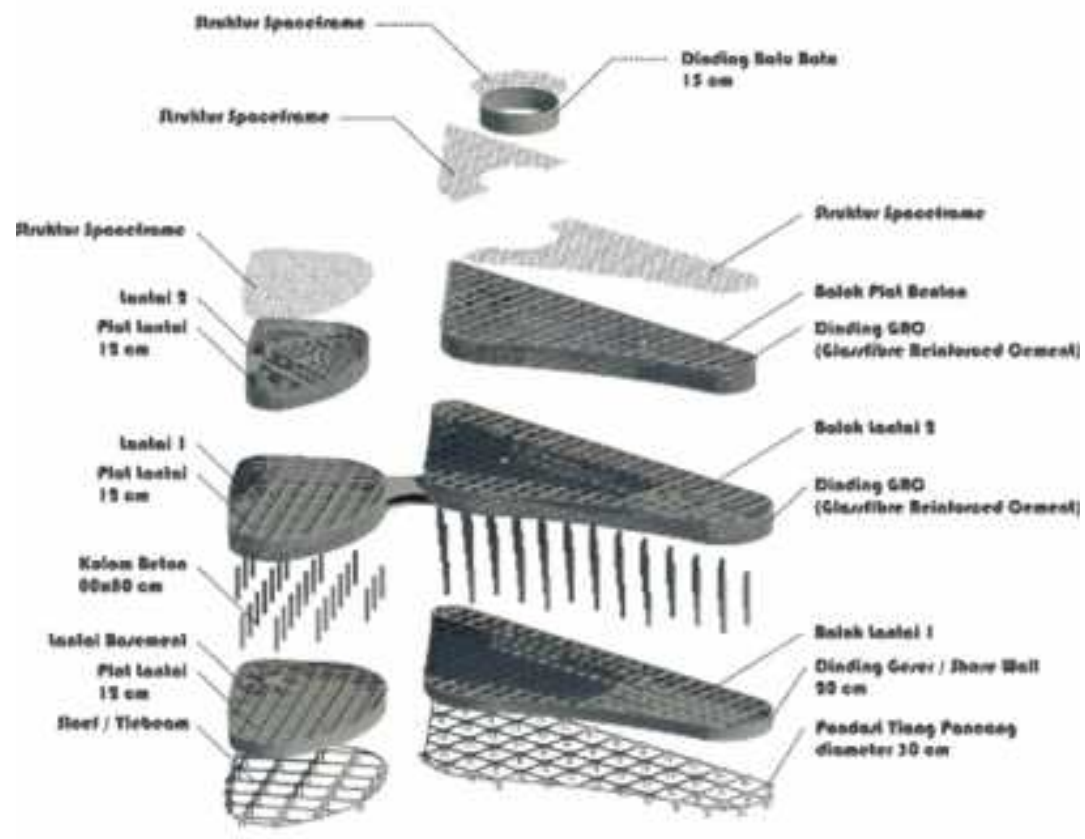

Gambar. Konsep Struktur Bangunan

Sumber : Olah Desain, 2015

2. Struktur utama bangunan yaitu kolom beton. Untuk dinding bangunan didominasi dengan material kaca yang mampu meminimalisir transfer panas kedalam bangunan, kaca ini juga berfungsi sebagai fasad bangunan sedangakan untuk ruangan pada dalam bangunan tetap menggunakan pasangan batu bata. Selain itu, pada sisi bangunan diberi over stage yang berfungsi untuk meminimalisir cahaya matahari langsung kedalam bangunan. Sedangkan untuk lantai bangunan akan digunakan material keramik.

3. Untuk perencanaan struktur atas (upper struktur) akan menggunakan struktur bentang lebar untuk mendapatkan ruang bebas kolom yang cukup besar. Jenis struktur bentang 
lebar yang digunakan yakni struktur rangka batang. Rangka batang adalah susunan elemenelemen linier yang membentuk segitiga atau kombinasi segitiga, sehingga menjadi bentuk rangka yang tidak dapat berubah bentuk diberi beban eksternal tanpa adanya perubahan bentuk pada satu atau lebih batangnya. Setiap elemen tersebut dianggap tergabung pada titik hubungnya dengan sambungan sendi. Sedangkan batang-batang tersebut dihubungkan sedemikian rupa sehingga beban dan reaksi hanya terjadi pada titik hubung.

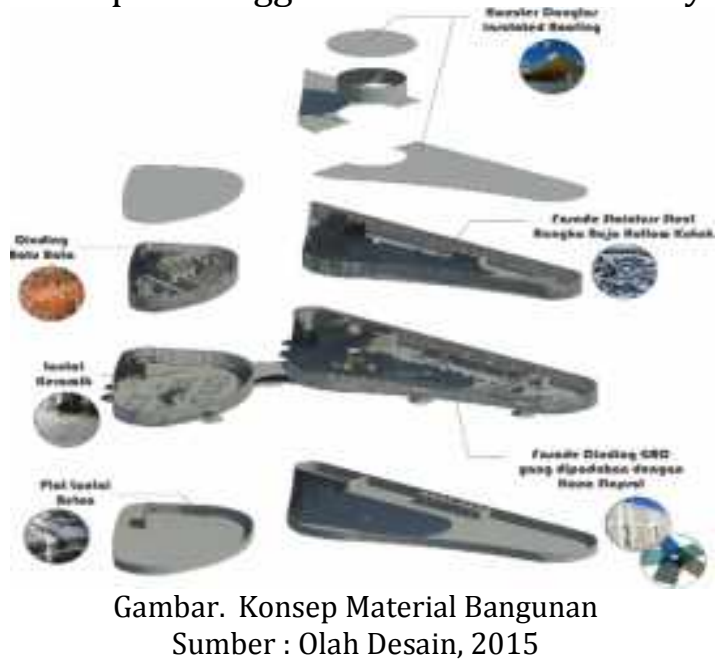

D. Tata Ruang/Layout Bangunan

Bangunan Utama terdiri dari dua lantai, dimana lantai satu terdiri dari pedagang los-los sedangkan lantai dua terdiri dari pedagang kios.
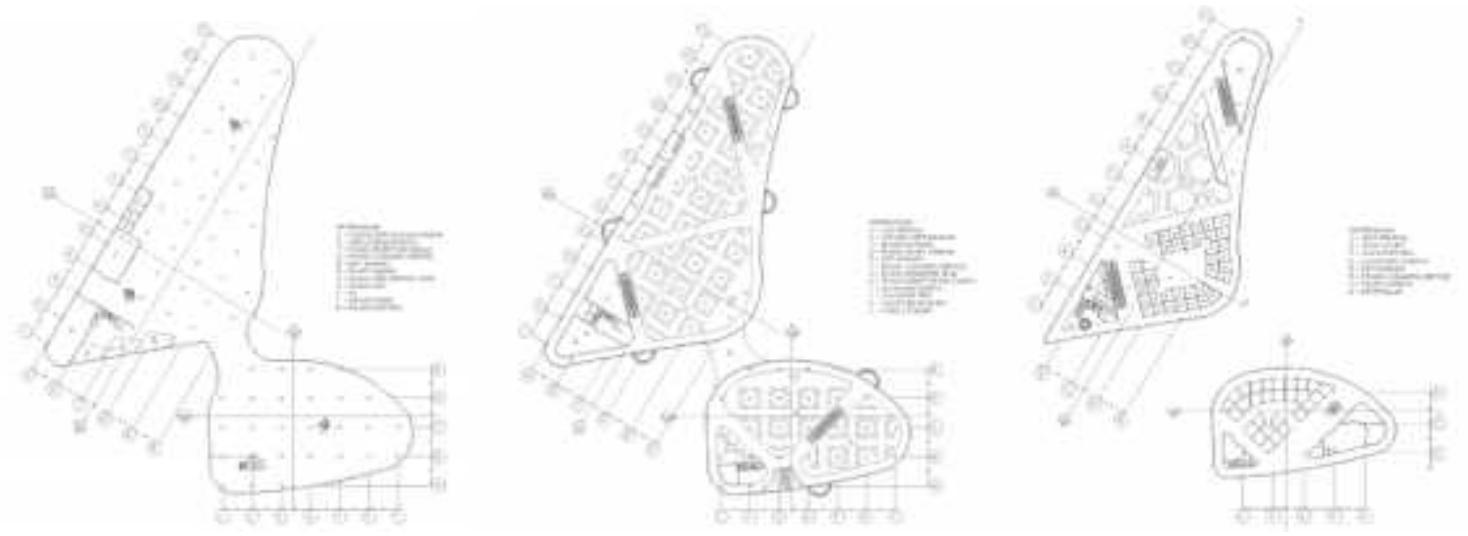

Gambar. Denah Bangunan Pasar

Sumber : Hasil Desain, 2015

\section{E. Sistem Utilitas Bangunan}

1. System Fire Protection atau disebut juga dengan System Fire Alarm (Sistem Pengindra Api) adalah suatu sistem terintegrasi yang di desain untuk mendeteksi adanya gejala kebakaran, untuk kemudian memberi peringatan (warning) dalam sistem evakuasi dan ditindaklanjuti secara otomatis maupun manual dengan sistem instalasi pemadam kebakaran (system fire alarm).

2. Penggunaan dinding dari material kaca akan membantu dalam memaksimalkan pemanfaatan cahaya matahari. Adapun penggunaan material kaca yang digunakan yaitu kaca stopsol yang memberikan perlindungan yang bagus dari panas matahari dengan cara 
merefleksikan kembali panas yang datang dari matahari sehingga tidak merusak barang dagangan yang ada di dalam bangunan.

3. Pencahayaan buatan menggunakan lampu TL pada area lapak-lapak dagangan dan area food court. Sedangkan untuk lampu LED digunakan pada area kantor pengelola, administrasi dan lavatory.

4. Penghawaan alami yang digunakan dengan memaksimalkan bukaan untuk aliran udara dari selatan ke utara. Sementara untuk penghawaan bukaan digunakan AC Split pada area kantor pengelola dan administrasi.

5. Jaringan air bersih berasal dari PDAM dan pembuatan sumur bor yang dilengkapi pompa deep weel.

6. Untuk kotoran padat dan cair yang berasal dari lavatory dialirkan pada saluran terturup ke septicktank kemudian ke bak peresapan. Pembuangan air bekas cucian, air bekas pembersihan pada ruang penjualan disalurkan melalui saluran semi terbuka yang mudah dibersihkan dan selanjutnya ke roil kota.

7. Escalator digunakan untuk memperlancar aksebilitas manusia dan barang didalam bangunan.

8. Menerapkan pengelolaan sampah, yaitu adanya pemisahan antara sampah organicanorganik yang tersedia di setiap blok ruang pasar baik di dalam bangunan atau di luar bangunan kemudian diangkut ke TPS untuk diolah menjadi pupuk, barang daur ulang, dan sisanya diangkut ke TPA.

\section{F. Konsep Arsitektur Modern}

Konsep ruang pada arsitektur modern yaitu ruang tidak terbatas meluas kesegala arah, ruang terukur/terbatasi/terlihat bayangan strukturnya (segi empat) arsitektur dipahami dalam tiga dimensi, ruang dari arsitektur modern memiliki hubungan dengan pengamat. Ruang yang didalam merupakan eksperimen ruang tak terbatas dengan partisi yang dapat diterusuri melalui ruang-ruang yang dilalui. Pola perletakan ruang lebih mengalir dan berurutan berdasarkan proses kegiatan.

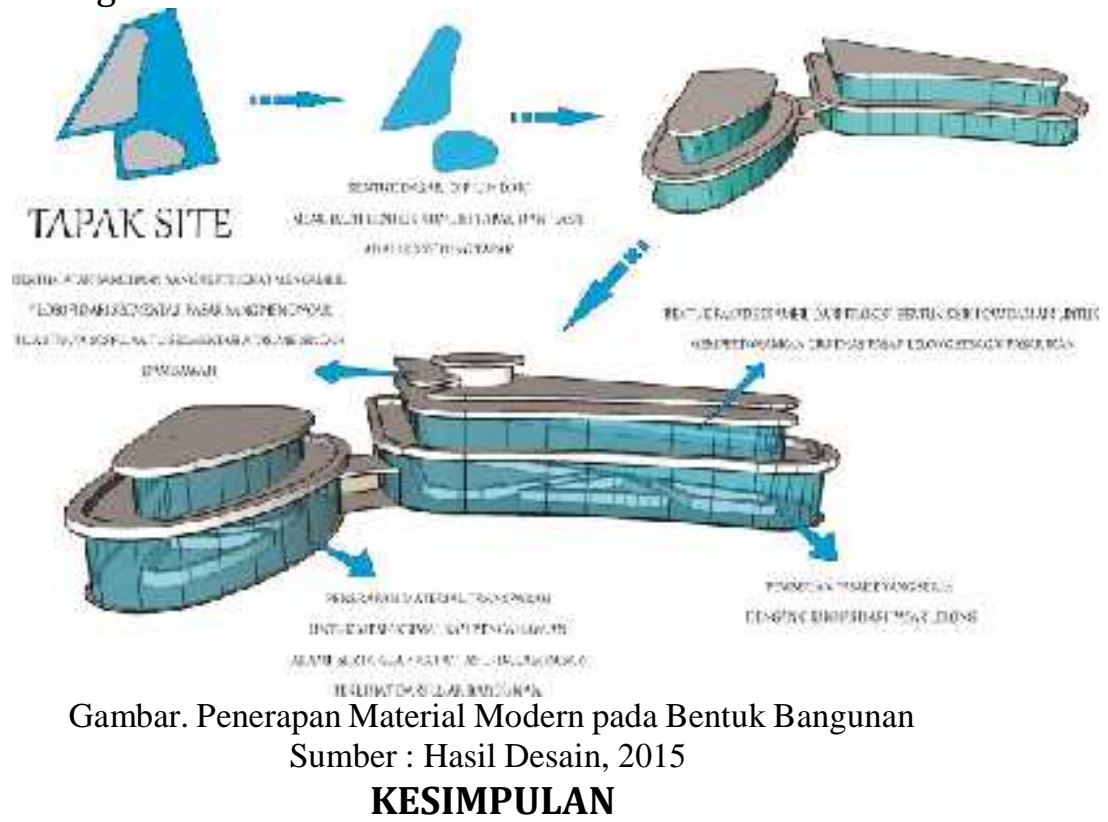

Penerapan konsep Modern yang di terapkan pada pasar tradisional Lelong dengan menganalisa potensi dan kelemahan pada tapak. Konsep pengolahan tapak Building coverage ratio sebesar 30 : 70. Dimana lahan yang terbangun sebagai lantai dasar bangunan sebesar 30\% dari 
luas tapak. Dan luas lahan yang tidak terbangun sebesar $70 \%$ sebagai open space termasuk area parker, jalan, taman, kafetaria. Penggunaan 30\% lahan untuk bangunan efektif untuk menyediakan banyak ruang terbuka dalam tapak yang dapat memberikan keleluasaan untuk menempatkan bangunan di tengah tapak sehingga semua sisi bangunan dapat memperoleh akses view kelingkungan sekitar. Konsep zoning dibagi menjadi 2 yaitu zoning horizontal (tapak) dan zoning vertikal (bangunan). Konsep bentuk bangunan mengikuti kondisi tapak serta hasil dari pengolahan tapak dan pengolahan zoning. Pada sisi fasad diambil dari filosofi ikan dan air untuk mempertahankan ciri khas dari tapak yang terpilih (Pasar Lelong). Pemilihan material bangunan menggunakan material modern seperti kaca yang memaksimalkan pencahayaan serta memperhatikan bahan yang bisa disesuaikan dengan bentuk fasad. Penataan ruang dalam dengan menerapkan system zoning dan kebutuhan ruang. Dibutuhkan sebuah kajian lebih mendalam mengenai arsitektur modern terkhusus dalam hal pengelolahannya dan perawatan bangunan sehingga pasar tradisional yang kumuh dan semrawut menjadi pasar yang bersih serta nyaman.

\section{DAFTAR REFERENSI}

Amin, Fasihul. (2012). Eksistensi Pasar Tradisional Akibat Munculnya Pasar Modern (Studi Kasus di Pasar Dinoyo Malang). Malang : Jurusan Manajemen Universitas Islam Negeri Malang

Djuprianto (2008). Pasar Induk Agrabisnis di Kec. Anggeraja Kab. Enrekang. Makassar : Jurusan Arsitektur Universitas 45 Makassar

Izza, Nahdliyul. (2010). Pengaruh Pasar Modern Terhadap Pedagang Pasar Tradisional (Studi Pengaruh Ambarukmo Plaza Terhadap Perekonomian Pedagang Pasar Desa Caturtunggal Nologaten Depok Sleman Yogyakarta). Yogyakarta : Jurusan Pengembangan Masyarakat Islam Konsentrasi Pengembangan Masyarakat Universitas Islam Negeri Sunan Kalijaga Yogyakarta

Nasichin, Choirun (2010). Perancangan Kembali Pasar Karangploso Kabupaten Malang (Tema: Sustainable Architecture). Malang : Jurusan Arsitektur Universitas Islam Negeri Malang

Neufert, Ernst. 2002. Data Arsitek Jilid 2. Jakarta : Erlangga

Oktavina, Galuh. (2011). Redesain Pasar Tradisional Jongke Surabaya.

Rahayu, Reski. (2011). Redesain Pasar Terong Makassar. Makassar : Jurusan Arsitektur Universitas Hasanuddin Makassar

Ramadhan, Fathur. (2011). Hotel Terapung di Gili Air Lombok Barat Nusa Tenggara Barat dengan Pendekatan Arsitektur Modern. Makassar : Jurusan Arsitektur Universitas Islam Negeri Makassar

Sumalyo, Yulianto. 2005. Arsitektur Modern Akhir Abad XIX dan Abad XX Edisi ke-2. Yogyakarta : Gadjah Mada University Press

Sumiati. (2010). Pasar Tradisional dengan Konsep Modern di Kab. Manokwari. Makassar : Jurusan Arsitektur Universitas 45 Makassar

https://www.facebook.com/sppitegal/posts/1404762759745530/, diakses pada tanggal 8 September 2014

https://www.academia.edu/8745988/Pencemaran_Air_di_Pasar_Terong, 9 September 2014 